\title{
Telaah Historis-Hermeneutis Hadis-Hadis Tentang Ayah
}

\author{
Hardivizon \\ Institut Agama Islam Negeri (IAIN) Curup, Indonesia \\ hardivizon@iaincurup.ac.id
}

\begin{abstract}
This study aims to find new meanings of hadiths regarding fathers, especially on the theme of: 1) the prohibition against hating fathers; 2) fathers entitled to the property of their children; 3) fathers as well as possible the gates of heaven. The side of study is the authenticity and meaning of the hadith. The approach that used in this study is hermeneutics offered by Hassan Hanafi in understanding the text of revelation as a source of law. Namely by building three consciousnesses; historical, eidetic, and praxis. This study found that in terms of quality, the three hadiths were in the position of maqbul, which could be accepted as proof. In meaning, it is understood that the role of a father in his child's life is very importance. Hating father is the result of making a child fall into kufr. No matter how bad the condition of a father, children should not hate or not admit him. The threat of a big sin was given by the Prophet to the person who did it. Child service must also be realized in the form of compensation for the father. Father's glory is symbolized as the best door of the heaven for the child.
\end{abstract}

Keywords: Father's role; Hadith; Hermeneutics; Hasan Hanafi

\begin{abstract}
Abstrak
Penelitian ini bertujuan mencari makna baru dari hadis-hadis mengenai ayah, terutama pada tema mengenai: 1) larangan membenci ayah; 2) ayah berhak atas harta anaknya; 3) ayah sebaik-baiknya pintu surga. Sisi yang diteliti adalah otentisitas dan makna hadis tersebut. Pendekatan yang digunakan adalah hermeneutika yang ditawarkan Hassan Hanafi dalam memahami teks wahyu sebagai sumber hukum. Yakni dengan membangun tiga kesadaran yaitu historis (asy-syu'ur at-tarikhy, eidetis (asy-syu'ur at-ta'ammuli), dan praksis (asy-syu'ur al- 'amali). Penelitian ini menemukan bahwa secara kualitas, ketiga hadis yang diteliti berada pada posisi maqbūl, yakni dapat diterima sebagai hujjah. Secara makna, dipahami bahwa betapa pentingnya peran seorang ayah dalam kehidupan seorang anak. Membenci ayah akibatnya adalah membuat seorang anak jatuh dalam kekufuran. Seburuk apapun kondisi seorang ayah, anak tidak boleh membencinya apalagi tidak mengakuinya. Ancaman dosa besar diberikan oleh Nabi terhadap orang yang melakukan perbuatan tersebut. Pengabdian anakpun harus diwujudkan dalam bentuk santunan harta untuk sang ayah. Kemuliaan ayah disimbolkan sebagai pintu surga terbaik bagi sang anak.
\end{abstract}

Kata Kunci: Peran Ayah; Hadis; Hermeneutika; Hassan Hanafi

FOKUS : Jurnal Kajian Keislaman dan Kemasyarakatan Vol. 3, No. 2, 2018

P3M Sekolah Tinggi Agama Islam Negeri (STAIN) Curup - Bengkulu

Available online: http://journal.staincurup.ac.id/index.php/JF

p-ISSN 2548-334X, e-ISSN 2548-3358 


\section{PENDAHULUAN}

Salah satu tema hadis yang menarik untuk diteliti adalah tentang ayah. Tidak banyak hadis yang berbicara mengenai hal ini. Namun, yang sedikit itu memunculkan sebuah persoalan yang tidak sederhana. Adanya pemuliaan yang berlebihan terhadap ibu, menurut penulis berimplikasi kepada sikap ayah dan ibu dalam mendidik anak. Hal ini sudah menjadi paradigma umum dalam masyarakat, bahwa ibu adalah yang paling utama dalam mendidik anak, sementara ayah berperan sebagai penyedia sarana untuk itu (the hunter).

Apabila melihat kembali realitas semacam ini, dan dibenturkan dengan hasil penelitian beberapa pakar di bidang psikologi perkembangan, maka akan didapat kesimpulan bahwa ayah haruslah memiliki peran yang sama dengan ibu dalam pendidikan anak. Seperti penelitian Slameto, atau Save M. Dagun yang menyimpulkan bahwa ayah yang turut berperan dalam pendidikan anak, menyebabkan meningkatnya tingkat kecerdasan sang anak di atas rata-rata. Selain itu, mereka juga mengatakan stigma yang beredar selama ini dengan meletakkan posisi ibu yang berlebihan sudah tidak relevan lagi. ${ }^{1}$

Kenyataan semacam ini jika dilihat dengan fenomena pemaknaan hadis akan sangat kontekstual sekali. Pertanyaannya adalah mengapa terdapat sejumlah hadis yang cenderung membedakan antara ayah dan ibu dalam hal pemuliaan dan penghormatan? Misalnya hadis tentang "surga di telapak kaki ibu", atau hadis tentang "dirimu dan hartamu adalah untuk ayahmu". ${ }^{2}$ Kedua hadis ini secara teks memberikan pemahaman, bahwa ayah tidak memiliki "surga", sehingga ia tidak patut untuk dihargai. Selain itu, ayah 'akan dipandang' hanya berhak atas harta anaknya, bukan penghormatannya. Lantas, apakah kedua orang tersebut

${ }^{1}$ Slameto Slameto, "Peranan Ayah Dalam Pendidikan Anak Dan Hubungannya Dengan Prestasi Belajarnya," Jurnal Satya Widya 15, no. 1 (2002); Save M. Dagun, Psikologi Keluarga: Peran Ayah Dalam Keluarga (Jakarta: PT. Rineka Cipta, 2013), 25.

${ }^{2}$ Dari sekian banyak banyak hadis yang dijumpai, penulis membagi ke dalam dua kategori kerangka besar hadis tentang Ibu dan Ayah. pertama, hadis-hadis ibu cenderung bersifat teosentris; surga-neraka, malaikat dan ampunan Allah, dan kedua, hadis-hadis ayah cenderung bersifat antroposentris; harta dan status sosial (nasab). 
tidak memiliki hak yang sama dari anaknya? Mengapa sepertinya ada pembedaan sikap anak terhadap ayah dan ibu?

Melalui penelitian ini, penulis mencoba mencari makna baru dari hadis tersebut, yaitu membongkar paradigma yang selama ini telah mengakar dalam mainstream pemikiran umat Islam. Dengan kata lain, mengarahkan pada upaya kritis terhadap teori/konsep pemikiran dan pemahaman yang ada dengan memberikan solusi, baik membangun teori baru atau memodifikasi teori sebelumnya untuk menjawab realitas saat ini. ${ }^{3}$ Dari kajian ini, diharapkan mampu menyelami lebih jauh sisi sanad dan matan hadis, dan meneliti bagaimana ruang lingkup yang mengitari munculnya hadis tersebut hingga mampu memproduksi makna baru yang lebih komprehensif, kontekstual, dan relevan dengan situasi kekinian.

Berangkat dari latar belakang masalah di atas, pertanyaan penting yang bisa diketengahkan adalah, bagaimana kualitas hadis-hadis tentang ayah dan bagaimana memahaminya? Juga, bagaimana kontekstualisasi makna hadis-hadis tersebut dalam era kekinian?

Hadis-hadis tentang ayah, tersebar dalam banyak tema. Penelitian ini, hanya memfokuskan pada tiga tema, yakni tentang larangan membenci ayah, hak ayah atas harta anaknya, dan ayah sebaik-baik pintu surga. Ketiga tema ini dipilih karena dapat mewakili relasi ayah dan anak dalam kehidupan; kasih sayang, harta, dan kehidupan akhirat.

Penelitian ini bertujuan untuk merekonstruksi pemahaman hadis mengenai tema ayah. Sisi-sisi yang akan ditelaah adalah pada dimensi historis hadis nabi, dari mulai turunnya hingga kajian seputar ma'ān alhadits. Dari upaya tersebut, dibuatlah konsep peta historis baik dari sisi hermeneutis ${ }^{4}$ dalam kajian Islam maupun relevansinya dalam kajian hadis, guna mendapatkan makna yang lebih kontekstual dan aplikatif.

3 Nurun Najwah, "Tawaran Metode Dalam Living Hadis," in Metodologi Penelitian Living Qur'an Dan Hadis, by Muhammad Mansyur (Yogyakarta: Teras, 2007), 133.

${ }^{4}$ Term hermeneutik pada dasarnya mencakup dua hal, pertama sebagai bentuk seni pemahaman; dan kedua, sebagai teori pemahaman sekaligus penafsiran baik bahasa maupun ekspresi-ekspresi lainnya selain bahasa. Sebagai teori penafsiran, tradisi 
Kajian ini tidak bertujuan 'menggugat' kemapanan posisi ibu dalam wilayah teosentris maupun antroposentris, atau dalam persepsi kebanyakan orang bahwa aspek paling berpengaruh dalam pendidikan anak adalah ibu. Hanya berupaya menggali kecenderungan dan merekonstruksi pemahaman hadis-hadis nabi yang seringkali mendikotomikan peran antara ayah dan ibu. Padahal dalam al-Qur'an jarang, atau bahkan bisa dikatakan tidak pernah ada ayat yang memisahkan peran keduanya. Kecuali ayat-ayat yang berbicara mengenai proses kelahiran dan menceritakan jerih payah seorang ibu dalam mengasuh dan menyusui bayi.

Dengan begitu menjadi jelas, bahwa kajian ini berupaya mendudukkan hadis dalam konteks yang lebih dinamis, dan mengembalikan pemaknaan, terutama mengenai ayah pada posisi yang sama dengan ibu bagi anak-anaknya. Upaya tersebut tidak lepas dari penggalian mendalam dengan pendekatan analisa historis-hermeneutis untuk mendapatkan penafsiran yang lebih objektif dan komprehensif.

Dalam menganalisis data, peneliti menggunakan pendekatan analisis historis-hermeneutis. Pada dasarnya, penggunan pendekatan analisis historis-hermeneutis berusaha merekonstruksi teks dari semua aspek. Pendekatan ini diadopsi dari hermeneutika Hassan Hanafi dalam memahami teks wahyu sebagai sumber hukum. Menurut Hanafi, ilmu ushul fiqh merupakan metode yang mendeskripsikan tindakan-tindakan dan tujuan-tujuan orang-orang mukallaf, sebagaimana wahyu mendeskripsikan dirinya yang disebut tendensi, maka ilmu itu menuntut

hermeneutika merentangkan segala cara untuk kembali ke filsafat Yunani kuno. Lihat C. Mantzavinos, "Hermeneutics," in The Stanford Encyclopedia of Philosophy, ed. Edward N. Zalta, Winter 2016 (Metaphysics Research Lab, Stanford University, 2016), https://plato.stanford.edu/archives/win2016/entries/hermeneutics/; Dalam hal ini, hermeneutika berusaha memandang bahwa makna dicari, dikonstruksi, dan direkonstruksi oleh penafsir sesuai konteks penafsir itu sendiri. Sehingga makna yang dihasilkan tidak pernah baku, dan senantiasa berubah tergantung bagaimana, kapan, dan siapa pembacanya. Selain itu, peristiwa pemahaman terjadi ketika cakrawala makna historis dan asumsi kita berpadu dengan cakrawala tempat karya itu berada. Hermeneutika melihat sejarah sebagai dialog hidup antara masa lalu, masa kini dan masa depan. Lihat juga Mudji Raharjo and Zainal Habib, Hermeneutika Gadamerian; Kuasa Bahasa Dalam Wacana Politik Gus Dur (Malang: UIN Malang Press, 2007), 55. 
tiga klasifikasi yang berangkat dari kesadaran. Oleh karena itu kesadaran harus berangkat dari; pertama, kesadaran sejarah (asy-syu'ur at-tarikhy), yang berfungsi menjamin validitas teks-teks wahyu dalam sejarah. Kedua, kesadaran eidetis (asy-syu'ur at-ta'ammuli) yang berfungsi memahami teks-teks wahyu dan interpretasinya yang diawali dengan ungkapan bahasa dan asbab an-nuzul - dalam konteks penelitian ini adalah asbab al-wurud. Ketiga, kesadaran praksis (asy-syu'ur al- 'amali) yang berfungsi merelevansikan nilai-nilai aturan hukum dalam permasalahan duniawi dan memanifestasikan tendensi-tendensi teks dalam sejarah. ${ }^{5}$

Dengan ungkapan lain, setelah makna objektif teks telah dipahami, maka selebihnya menerapkan pesan-pesan yang terkandung dalam teks hadis yaitu pesan-pesan atau ajaran-ajaran pada saat teks tersebut ditafsirkan. Maka dari itu, ketika seseorang yang mencari makna objektif teks, ia dituntut untuk memahami teks dalam segala momen, baik pada saat teks diucapkan maupun ditafsirkan dalam situasi dengan pendekatan baru dan berbeda. ${ }^{6}$

Sedangkan yang perlu ditekankan dalam penelitian ini, terkait dengan upaya merekonstruksi pemahaman suatu hadis adalah uji otentisitas. Maka dalam kajian ini akan digunakan teori otentisitas menurut Muhammad al-Ghazali. Bagi al-Ghazali, penetapan sebuah hadis matan hadis membutuhkan pengetahuan terhadap al-Qur'an al-Karim dan penguasaan tata cara pengambilan dalil-dalil yang ada di dalamnya. Selain itu, penetapan ini juga membutuhkan ilmu lain yang terkait dengan beragam berita yang dinukil sehingga penilaian dan koreksi antara bagian yang satu dengan lainnya.

${ }^{5}$ Hassan Hanafi, Islamologi 3: Dari Teosentrisme Ke Antroposentrisme, trans. Miftah Faqih and Fuad Mustafid (Yogyakarta: LKis, 2011), 22.

${ }^{6}$ Hans-Georg Gadamer, Truth and Method, trans. Ahmad Sahidah (Yogyakarta: Pustaka Pelajar, 2004), 371. 


\section{PEMBAHASAN}

Ada beberapa tema hadis-hadis yang membahas mengenai ayah. Dalam penelitian ini, peneliti memilih 3 tema, yakni:

\section{Jangan Membenci Ayah}

Rasulullah memerintahkan kita untuk menyayangi ayah dengan sepenuh hati. Membenci ayah, bisa berakibat buruk terhadap kita, sebagaimana tercantum dalam hadis beliau:

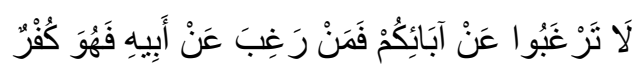

"Janganlah engkau membenci ayah, barang siapa yang membenci ayahnya, maka dia berada dalam kekufuran"

Dengan metode takhrīj bi al-lafz $h^{7}$, penulis menemukan informasi bahwa hadis ini ditakhrij oleh Imam Muslim ${ }^{8}$, Bukhāri ${ }^{9}$, dan Ahmad ibn Hanbal ${ }^{10}$.

Dalam kesempatan ini, hadis yang penulis teliti adalah jalur Bukhari dengan teks lengkap sebagai berikut:

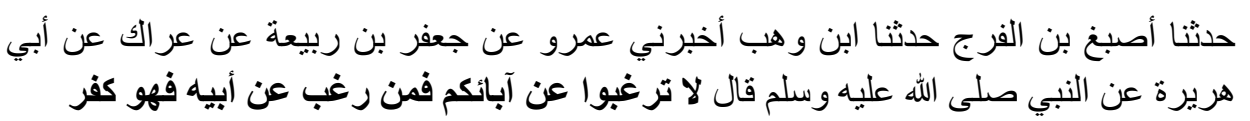

Setelah melakukan naqd terhadap para perawi hadis ini, yakni Bukhāri' ${ }^{11}$, Aṣbagh ibn al-Farj' ${ }^{12}$, Ibn Wahab ${ }^{13}$, 'Amru' ${ }^{14}$, Ja'far ibn

${ }^{7}$ A. J. Weinsink and W.Y. Mansink, Al-Mu'jam Al-Mufahrasy Li Alfazh Al-Hadits Al-Nabawi (Leiden: Brill, 1965), 2. 275.

${ }^{8}$ Muslim ibn Hujjaj Al-Qusyri Al-Naisabury, Șahih Muslim (Beirut: Dar Ihya' alKutub al-'Arabiyah, n.d.). kitab al-Iman, bab bayan hal iman man raghiba 'an abihi wa huwa ya'lamuhu, nomor 94.

9 Muḥammad Ismā’il al-Bukhāri, Șahih Al-Bukhārī (n.p: Dār Ibn Kas̄īr, 1993). kitāb al-farāiḍ, bāb man idda'ā ilā ghair ab̄̄hi, hadis nomor 6386.

${ }^{10}$ Ahmad ibn Hanbal, Musnad Ahmad Ibn Hanbal (Beirut: Dār Ihya' al-Turās al'Arabī, 1993). musnad Abū Hurairah, hadis nomor 10432

${ }^{11}$ Muhammad Abu Syuhbah, Fi Rihab Al-Sunnah Al-Kitāb Al-Șihāh Al-Sittah (Kairo: Majma’ al-Mabhūī al-Islāmiyyah, n.d.), 42.

${ }^{12}$ Syihab al-Din Abu al-Fadhl Ahmad ibn Hajar al-'Asqalani, Tahzib Al-Tahzib (Beirut: al-Turas al-'Arabi, 1993), 1.229.

${ }^{13}$ Ibid., 3. 295-297. 
Rabi' ah ${ }^{15}$, 'Irāk ibn Mālik ${ }^{16}$, dan Abu> Hurairah ${ }^{17}$ terlihat bahwa hadis ini diriwayatkan oleh para perawi yang 'adil lagi dhabith. Mereka dinilai oleh para ulama kritikus hadis dengan pujian tingkat tinggi dan tertinggi. Sanad antara para perawi tersambung, terdapat bukti kuat yang menyebutkan bahwa antara mereka saling bertemu pada masing-masing tingkatannya. Riwayat ini pun tidak ditemukan kejanggalan (syadz) maupun kecacatan ('illat). Karena syarat keshahihan hadis terpenuhi secara keseluruhannya, maka hadis ini dapat dikatakan sebagai hadis shahih.

Hadis di atas sering dikaitkan dengan hadis lain sebagai ekspresi kebencian terhadap ayah. Sehingga kebencian tersebut melahirkan sikap ketidakmauan seorang anak bernasab kepada orang tuanya yang asli. Dan ini dihukumi sebagai kufur bukan dalam arti keluar dari Islam, tetapi dalam konteks kufur nikmat. Tindakan ini lazim terjadi pada masa Jahiliah hal ini sudah diwanti-wanti oleh Rasulullah saw dalam sebuah hadis,

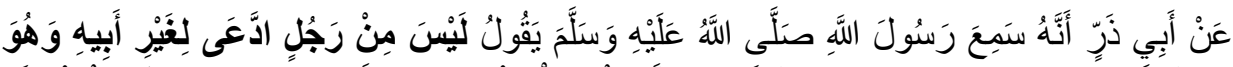

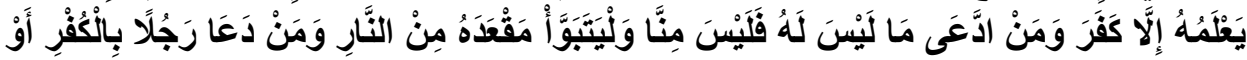

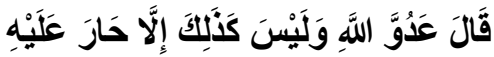
Abu Dzar mendengar Rasulullah saw. bersabda: Setiap orang yang mengaku keturunan dari selain ayahnya sendiri, padahal ia mengetahuinya, pastilah ia kafir (artinya mengingkari nikmat dan kebaikan, tidak memenuhi hak Allah dan hak ayahnya). Barang siapa yang mengakui sesuatu bukan miliknya, maka ia tidak termasuk golongan kami dan hendaknya ia mempersiapkan tempatnya di neraka. Barang siapa yang memanggil seseorang dengan kata kafir atau mengatakan musuh Allah, padahal sebenarnya tidak demikian, maka tuduhan itu akan kembali pada dirinya.

\footnotetext{
${ }^{14}$ Ibid., 4, 326-27.

${ }^{15}$ Ibid., 1, 377-78.

${ }^{16}$ Ibid., 4, 111-12.

${ }^{17}$ Ibid., 6, 479-82.
} 
Dalam kaitan dengan hadis di atas, anak adalah buah hati orang tuanya. Tidak ada orang tua yang rela menisbahkan anaknya kepada orang lain. Namun terkadang karena kebencian seorang anak terhadap ayahnya, ia rela menasabkan dirinya dengan orang lain. Pengangkatan anak dalam Islam tidak serta merta menghilangkan dan menghapus garis nasab anaknya.

Dalam kasus tabanniy (adopsi) atau pengangkatan anak orang lain sebagai anak sendiri, pada jaman Jahiliyah seorang mengangkat anak lelaki sebagai anaknya dengan mendapatkan hak seperti anak kandungnya. Dipanggil dengan memakai nama ayah angkatnya dan mendapatkan warisan. Rasulullah saw. mengangkat Zaid bin Hàritsah sebagai anaknya sebelum menjadi nabi. Para Sahabat memanggil Zaid dengan panggilan Zaid bin (anak) Muhammad hingga turun ayat: "Panggillah mereka (anak-anak angkat itu) dengan (memakai) nama bapak-bapak mereka”. (HR: Al Bukhari).

Dalam kasus Miqdad, dijelaskan dalam Fath al-Bari bahwasannya Ibnu Baththal mengatakan bukanlah ia dimasukkan dalam ancaman seseorang yang menisbahkan nasabnya kepada selain ayahnya. Akan tetapi, barang siapa merubah secara sengaja, sadar, dan pilihan, seperti lazim terjadi pada masa Jahiliah sampai turun ayat: "Panggilah mereka (anak-anak angkat itu) dengan (memakai) nama bapak-bapak mereka; itulah yang lebih adil pada sisi Allah, (Qs. Al-Ahzab [33]: 5) dan juga ayat: "Dia (Alloh) tidak menjadikan anak-anak angkatmu sebagai anak kandung-mu (sendiri). Yang demikian itu hanyalah perkataan di mulutmu saja. Dan Alloh mengatakan yang sebenarnya dan Dia menunjukkan jalan (yang benar).” (Qs. Al 'Ahzab [33]: 4)

Maka, sejak itulah setiap orang menasabkan kepada ayah kandungnya yang sebenarnya. Lalu mereka meninggalkan bernasab kepada orang-orang yang mengangkatnya sebagai anak. Sebagian masih ada yang menasabkan dirinya dengan orang tua angkatnya sekadar sebagai tanda, bukan nasab seperti Miqdad bin Aswad. Karena Aswad bukan ayah yang sebenarnya, tetapi ia mengangkatnya. Sedangkan nama 
ayahnya adalah Amr bin Tsa'labah bin Malik bin Rabi' al-Bahrani, yang bersambung kepada anak turun Bani Kindah atau al-Kindi. ${ }^{18}$

Selain itu, Islam juga melarang tawaruts (saling mewarisi) antara anak dan ayah angkat. Ketika Allah Swt me-naskh hukum legalisasi anak angkat maka Allah Swt membolehkan untuk menikahi istri anak angkat atau sebaliknya. Allah saw. telah menikahkan Rasulullah dengan Zainab binti Jahsy Al-'Asadiyyah bekas istri Zaid bin Haritsah. Hal ini bertujuan agar orang-orang mukmin tidak keberatan menikahi istri-istri anak-anak angkat mereka, apabila anak-anak angkat itu telah menyelesaikan keperluannya daripada isterinya (setelah talak dan habis 'iddahnya). Sebagaimana firman Allah swt., "Maka tatkala Zaid telah mengakhiri keperluan terhadap isterinya (mencerai-kannya), Kami kawinkan kamu dengan dia supaya tidak ada keberatan bagi orang mu'min untuk (mengawini) isteri-isteri anak-anak angkat mereka, apabila anak-anak angkat itu telah menyelesaikan keperluannya daripada isterinya."'(QS: Al-Ahzab [33]: 37)

Dengan demikian, menasabkan silsilah keturunan ayah angkat kepada anak angkat adalah sebuah kedustaan, mencampurbaurkan nasab (silsilah keturunan), mengubah hak-hak warisan yang mengakibatkan pemberian warisan kepada yang tidak berhak dan menghilangkan hak waris bagi yang berhak. Selain itu, juga akan terjadi percampuran antara yang halal dan yang haram dengan berkhalwat yaitu berkumpulnya mahram dengan yang bukan. Tindakan semacam ini seakan-akan mengingkari nikmat Allah berupa pengingkaran terhadap air mani yang dititipkan ke rahim ibunya yang hakiki, air mani yang menjadikan asal penciptaannya, dan mengharamkan yang halal dengan pernikahan. Tindakan ini benar-benar dikecam oleh Rasulullah Saw. dan mengancam pelakunya dengan keharaman surga, sebagaimana dalam sebuah hadis disebutkan, "Barangsiapa yang dengan sengaja mengakui (sebagai ayah)

${ }^{18}$ Syihab al-Din Abu al-Fadhl Ahmad ibn Hajar al-“Asqalani, Fath Al-Bari (Beirut: Dar al-Fikr, 1996), 19, 171. 
seorang yang bukan ayahnya sedang ia mengetahui, maka Surga haram buatnya" (Hr. Bukhari dan Muslim).

\section{Ayah Berhak atas Harta Anaknya}

Rasulullah saw. melarang umatnya untuk menelantarkan ayah. Beliau bahkan mengatakan bahwa harta anak adalah harta ayahnya. Hal ini berdasarkan hadis beliau yang berbunyi:

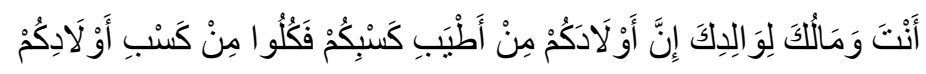

"Kamu dan hartamu adalah milik orang tuamu, sesungguhnya anak-anak kalian termasuk hasil usaha kalian yang terbaik. Maka makanlah dari usaha anak-anak kalian".

Melalui metode takhrijj bi al-lafz $h^{19}$, penulis menemukan informasi bahwa hadis ini ditakhrij oleh Abū Dāwūd ${ }^{20}$ sebanyak satu riwayat dan Aḥmad ibn Ḥanbal sebanyak dua riwayat. ${ }^{21}$

Di sini, jalur yang penulis teliti adalah yang melalui Abu Dawud, dengan teks hadis sebagai berikut:

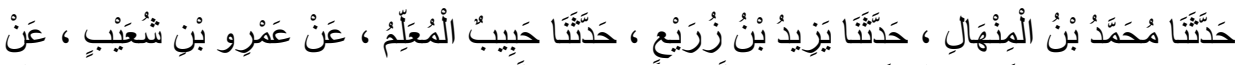

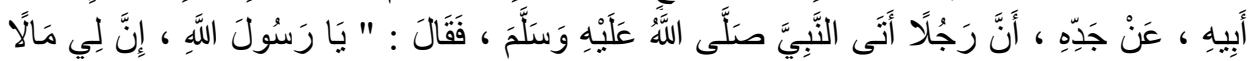

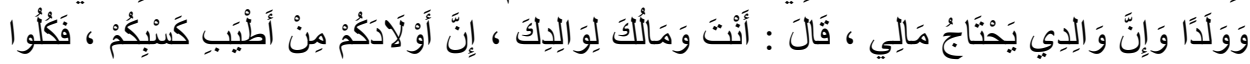

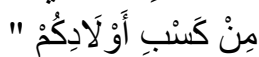

Setelah melakukan penelusuran dan penelitian terhadap para perawi hadis ini, yakni Muḥammad ibn Minhāl ${ }^{22}$, Yazīd ibn Zurai ${ }^{23}$, Habī̄b alMu'allim²4, 'Amrū ibn Syu'aib²5, Ayah 'Amrū ibn Syu'aib (Syu'aib ibn

${ }^{19}$ Weinsink and Mansink, Al-Mu'jām Al-Mufahrasy, 6, 10.

${ }^{20}$ Imam Abū Dāwūd, Sunan Abū Dāwūd (Beirut: Maktab ad-Dirāsāt wa al-Buhuts fì Dār al-Fikr, n.d.). kitāb al-ijārah, bāb fi al-rijāl ya'kul min māli waladihi, hadis nomor 3066

${ }^{21}$ Ahmad ibn Hanbal, Musnad Ahmad Ibn Hanbal. musnad 'Abdullāh ibn 'Amrū ibn al-'Aș, hadis nomor 6501 dan 6825.

22 al-'Asqalani, Tahzib Al-Tahzib, 5, 303-4.

${ }^{23}$ Ibid., 6, 205-6.

${ }^{24}$ Ibid., 1, 439.

${ }^{25}$ Ibid., 4, 347-51. 
Muhammad) ${ }^{26}$, dan Kakek 'Amrū ibn Syu'aib ('Abdullāh ibn 'Amrū $)^{27}$, diketahui bahwa salah satu perawi hadis ini, yaitu Habib al-Mu'allim memiliki kesiqahan yang tidak sempurna. Namun, ketersambungan sanadnya dapat dijamin, karena masing-masing perawi terbukti saling terhubung. Matan dari Abu Daud maupun Ahmad memiliki kesamaan redaksi. Sehingga tidak ada yang menyalahi antara satu sama lain. Dari sini, dapat dikatakan bahwa hadis ini berstatus hasan, karena kurangnya ketsiqahan salah seorang perawinya.

Hadis ini membicarakan tentang pengakuan harta anak atas orang tua. Hadis ini sekaligus menyinggung hak dan kewajiban anak terhadap orang tuanya, baik ibu maupun ayah. Secara historis hadis ini turun berkenaan dengan seorang laki-laki yang mengadu kepada Nabi Saw. ia berkata: "Wahai Rasulullah, sesungguhnya saya memiliki harta dan anak, sedangkan ayahku bermaksud hendak menghabiskan harta itu."Maka Rasulullah Saw. menjawab: "Engkau dan hartamu adalah milik ayahmu".

Secara lebih detail, At-Tabrani meriwayatkan hadis ini berdasarkan hadis dari Jabi $>$ r ibn Abdulla $>$ h.

Suatu ketika, ada seorang laki-laki yang datang menemui Nabi Saw. dan mengadukan permasalahannya. Dia berkata: "Ya Rasulullah, sesungguhnya ayahku ingin mengambil hartaku...." Kemudian Nabi berkata, "Pergilah, dan bawalah ayahmu kemari". Pada saat bersamaan Malaikat Jibril turun menyampaikan salam dan pesan dari Allah kepada beliau. Jibril berkata, "Ya, Muhammad, Allah telah mengucapkan salam kepadamu, dan berpesan jika orang tua itu datang, maka kamu harus menanyakan segala yang dikatakan di dalam hatinya, yang tidak didengar oleh telinganya." Maka tatkala orang tua itu tiba, kemudian Nabi pun bertanya, "Mengapa anakmu mengadukanmu? Apa benar engkau ingin mengambil hartanya?" Lelaki tua itu menjawab, "Tanyakan kembali kepadanya wahai Rasulullah, bukankah saya menafkahkan uang

\footnotetext{
${ }^{26}$ Ibid., 2, 509.

${ }^{27}$ Ibid., 3, 218-19.
} 
itu untuk beberapa orang pamannya (saudara ayahnya) atau bibinya (saudara ibu), atau untuk keperluan saya sendiri?" Rasulullah bersabda: "Lupakan hal itu. Sekarang, ceritakan kepadaku apa yang engkau katakan dalam hatimu dan tak pernah didengar oleh telingamu!" Maka orang tua itu berkata: "Demi Allah, ya Rasulullah, dengan ini Allah Swt. berkenan menambah kuat keimananku dengan kerasulanmu. Aku telah mengatakan apa yang belum pernah didengar telingaku." Dan Nabi pun terus mendesak, "Katakanlah, aku ingin mendengarnya." Orang tua itu kemudian berkata, "Saya katakan ini kepadanya, 'Aku mengasuhmu semenjak bayi dan memeliharamu sewaktu muda. Semua hasil jerihpayahku kau minum dan kau reguk puas. Bila kau sakit di malam hari, hatiku gundah dan gelisah. Lantaran sakit dan deritamu, aku tak bisa tidur dan resah, seakan-akan akulah yang sakit, bukankah kau yang menderita. Lalu air mataku berlinang-linang dan meluncur deras. Hatiku takut engkau disambar maut, padahal aku tahu ajal pasti akan datang. Setelah engkau dewasa, dan telah tercapai apa yang kau cita-citakan, kau balas aku dengan tindakan kasar, keras, dan kejam, seakan-akan engkaulah pemberi kenikmatan dan keutamaan. Sayang sekali kau tak maтри penuhi hak ayahmu, kau perlakukan aku seperti tetangga jauhmu. Engkau selalu menyalahkan dan membentakku, seolah-olah kebenaran selalu menempel pada dirimu..., seakan-akan kesejukan bagi orang-orang yang benar sudah dipasrahkan.' Selanjutnya Jabir berkata, "Pada saat itu Nabi langsung memegangi ujung baju pada leher anak itu seraya berkata: "Engkau dan hartamu milik ayahmu!",28

Dari hadis di atas, ternyata ditemukan bahwa laki-laki tersebut seorang yang bakhil, yang tidak mau menafkahi orang tuanya yang selama ini telah menafkahi dan menyayanginya. Dalam syarh Ibnu Bat $\}$ t al, bahwa maksud 'anta wa ma>luka li abi $>k a$ ' adalah dalam hal ketaatan dan kepatuhan bukan dalam hal kepemilikan yang lazim. ${ }^{29}$ Artinya, anak

${ }^{28}$ Al-Imam Ath-Thabrani, Al-Mu'jam Al-Ausath (Beirut: Dar al-Kutub al-Ilmiyah, 2012), 14, 336.

${ }^{29}$ Abu al-Hasan 'Ali ibn Khalaf ibn 'Abd al-Malik Ibnu Batthal, Syarah Shahih Al Bukhari Li Ibni Batthal (n.p: Maktabah al-Rusyd, 2008), 6, 91. 
harus patuh dan taat kepada orang tua, dan sekaligus mau memberikan nafkah kepadanya.

Dalam 'Aun al-Ma'bu>d dijelaskan dengan matan lain, yaitu perbedaan dalam kalimat 'yah $t a>j u$ ' dan 'yajta>h\}u' yang memiliki makna sama, yaitu yasta'siluhu fa ya'ti 'alaihi atau memerlukan dan dia (orang yang diharapkan bantuannya) datang kepadanya. Demikian pula al-Munzhir, sebagaimana dikutip oleh Syamsul H\}aq, bahwa hadis ini diriwayatkan oleh Ibnu Ma>jah dengan perbedaan dalam kalimat ih\}tija $>j$ dengan mengacu pada hadis 'Amr ibn Syu'aib. Sedangkan Ibnu $\mathrm{Ma}>\mathrm{jah}$ mengambil hadis dari Muhammad ibn al-Munkadir dari Ja>bir ibn Abdullah, dan mengatakan bahwa sanad hadis tersebut s\iqah. ${ }^{30}$

Sebagaimana disebutkan di atas tentang kebutuhan harta yang dibutuhkan orang tuanya, karena ia (anak) merupakan sebab nafkah tersebut. Sementara ukuran kebutuhan nafkah tersebut sangat banyak dan tidak terbatas. Akan tetapi dengan mengacu pada hadis tersebut, maka maknanya adalah jika dia memerlukan hartamu, ambillah hartamu sesuai dengan kebutuhannya sebagaimana ia mengambil hartanya sendiri. Dan jika kamu tidak memiliki harta tetapi memiliki pekerjaan, maka kewajibanmu untuk bekerja dalam rangka menafkahinya. ${ }^{31}$

Secara sekilas hadis di atas tampak adanya ketimpangan dalam perlakuan terhadap ayah. Namun apabila dilihat matan secara keseluruhan, terlebih dengan mengamati $a s b a>b$ al-wuru $>d$ dari hadis di atas, maka tampak jelas bahwa anak laki-laki tersebut yang bersikap tidak menghargai terhadap jerih-payah orang tuanya. Lebih dari itu, Jabi>r menjelaskan bahwa pada saat itu Nabi tampak sangat marah dengan ekspresinya memegangi kerah baju (at-tala $>b i>b)$ laki-laki tersebut. Ini menegaskan bahwa laki-laki tersebut adalah pihak yang salah, yang harus diperingatkan.

${ }^{30}$ Abu ath-Thayyib Muh 3 ammad Syams al-'Azhim Abadi, 'Aun Al-Ma'Bud (CD Maktabah Syamilah, versi 02.11, n.d.). bab fi ar-Rija $>l$ ya'kulu min ma>li walidihi., 8, 26.

${ }^{31}$ Ibid. 
Dalam Islam, orang tua tidak sebatas hanya ayah atau ibu saja. Tetapi keduanya merupakan korporasi yang harus dihormati dan dihargai. Hal ini ditegaskan juga dalam ayat al-Qur'an yang tidak membedakan antara keduanya dalam Qs. Al-Isra>' [17]: 23-24, bahwasannya Allah melarang manusia untuk berlaku kasar terhadap orang tua. Lebih dari itu, ayat ini dan beberapa ayat lainnya selalu didahului dengan perintah ketauhidan. Ini menyiratkan bahwa kedudukan orang tua, terutama ibu adalah tiga tingkat di bawah Allah dan Rasul-Nya. Bahwasannya setelah ketauhidan yang meliputi Allah dan Rasul, maka perintah berikutnya adalah "jika salah seorang di antara keduanya atau kedua-duanya sampai berumur lanjut dalam pemeliharaanmu, maka sekali-kali janganlah kamu mengatakan kepada keduanya perkataan 'ah' dan janganlah kamu membentak mereka, serta ucapkanlah kepada mereka perkataan yang mulia." Ayat ini memerintahkan untuk senantiasa berbuat baik kepada kedua orang tua.

Dalam tafsir Thabari ditegaskan, bahwa larangan mengatakan 'ah' (uff) berarti larangan membentak yang terlihat menyakitkan bagi keduanya, atau bagi orang lain. Akan tetapi bersabarlah kepada keduanya, dan berharaplah imbalan atas kesabaranmu kepada keduanya, sebagaimana mereka berdua telah bersabar kepadamu sepanjang waktu kecilmu. ${ }^{32}$

Secara lebih tegas al-Qur'an menyebutkan kesetiaan orang tua terhadap anaknya, yaitu dalam nasihat Luqma>n dalam Qs. Luqma>n [31]: 13-15. Pada ayat ini, terdapat medan semantik yang sangat kuat sekali, bahwa Allah sangat memperhatikan kedudukan orang tua, terlebih ibu yang telah mengandung selama kurang lebih sembilan bulan. Dalam surat Luqma>n secara lebih tegas memberikan batasan ketaatan kepada orang tua, dengan standar tidak menyekutukan Allah dan Rasul. Tetapi penekanan ayat tersebut adalah pada kalimat terakhir. Dalam arti, berbuat baik kepada kedua orang tua hukumnya wajib. Kewajiban seorang anak untuk berbuat baik tersebut melampaui batas agama. Sehingga meski

${ }^{32}$ Abu Ja'far Muhammad Ibn Jarir Al-Tabari, Jami' Al-Bayan: 'an Ta'wil Ay AlQur'an (Beirut: Dar al-Kutub al-Ilmiyah, 2009), 15, 45-46. 
orang tua berbeda keyakinan dengan anak, tetapi tidak menggugurkan kewajiban berbuat baik kepada mereka.

Salah satu perbuatan baik itu adalah memberi nafkah kepada orang tua ketika kedua memang membutuhkan dan tidak mampu bekerja lagi. Pemberian nafkah tersebut selain karena kewajiban, dikuatkan dengan hadis lain, bahwa harta milik anak adalah milik orang tuanya juga. Hadis tersebut diriwayatkan dari 'Aisyah:

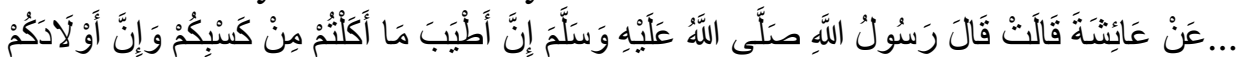

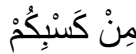

Dari 'Aisyah ra. Rasulullah bersabda: "sebaik-baik yang engkau makan adalah hasil jerih payahmu, dan anak merupakan salah satu dari hasil jerih-payahmu." Dalam riwayat Ahmad terdapat tambahan kalimat ' $\mathrm{fa}$ kulu> hu hani> 'a yang berarti makanlah dengan enak.

Menurut Abu 'Isa> bahwa hadis ini adalah h\}asan $s\} a h\} i>h\}$. Sebagian ulama mengatakan, sesungguhnya kekuasaan seorang ayah meliputi harta anaknya. Maka seorang ayah diperbolehkan mengambil sesuai dengan keinginannya. Sebagian mengatakan, tidak diperkenankan mengambilnya kecuali sesuai kebutuhannya. ${ }^{33}$

Kedua hadis di atas pada dasarnya adalah anjuran yang sangat kuat untuk memperhatikan kehidupan orang tuanya, atau ayahnya. Jangan sampai seorang anak mengabaikan dan menyia-nyiakan orang tua dengan berlaku tidak baik. Hadis di atas tidak serta merta dimaknai secara simplikatif dengan mengakuisisi harta anak secara keseluruhan. Ada hukum-hukum dan aturan-aturan yang mengatur kepemilikan anak, sekaligus menjawab kepentingan seorang ayah. Sehingga ayah juga memiliki hak atas harta anak tetapi dalam batasan yang telah ditetapkan, dan anak juga memiliki hak atas hartanya sendiri.

${ }^{33}$ Imam Turmudzi, Sunan At-Turmudzi (Beirut: Dar al-Fikr, 1994), 5, 210. Hadis ini juga diriwayatkan antara lain oleh An-Nasa $>$, Ibnu Ma $>$ jah, Ahmad, dan alBaihaqi>. 
Dalam Islam terdapat aturan-aturan mengenai harta anak. Meski dikatakan bahwa ayah memiliki hak atas harta anak, bukan berarti anak tidak memiliki hak atas hartanya sendiri. Dalam beberapa hal, seperti wasiat, warisan, zakat dan lain sebagainya, seorang anak berhak menggunakan hartanya sendiri di jalan tersebut tanpa harus meminta izin kedua orang tuanya. Dengan begitu kepemilikan ayah tidak menghalangi anak atas hartanya sendiri yang diperolehnya dari bekerja, hibah, dan warisan. Sementara seorang ayah juga tidak serta merta menguasai harta anak secara keseluruhan, namun sesuai dengan kebutuhannya.

Berbuat baik kepada orang tua tidak sebatas pemberian nafkah semata, tetapi juga dalam ucapan, tindak-tanduk, maupun perbuatan baik yang sifat sirr, atau sesuatu dalam hati. Misalnya tidak menggunjing di kala mereka tidak ada, atau tidak berprasangka buruk dan menyakiti perasaannya. Demikian pula perbuatan baik itu tidak terbatas sifatnya, dan yang membatasi adalah hak anak itu sendiri. Masing-masing anak dan orang tua pada dasarnya memiliki hak dan kewajiban yang harus ditunaikan. Jika terjadi perbedaan pendapat, maka juga harus dimusyawarahkan dan dibicarakan dengan baik, dengan dilandasi rasa kasih sayang dan saling memiliki. ${ }^{34}$

Namun demikian, tanpa perjuangan seorang ayah, seorang ibu tidak akan melahirkan anaknya, dan ini menandakan adanya ikatan batin yang sama kuatnya dan harus terus dihargai sampai akhir hayatnya. Dalam kasus kepemilikan harta tersebut, kepemilikan ayah atas harta itu untuk merawat dan menafkahi orang tua yang sudah tidak lagi mampu bekerja. Dengan kata lain, ayahlah yang lebih berhak atas hartamu (anak), karena ia menjadi sebab kelahiranmu ke dunia, dan keberadaanmu itu menyebabkan adanya hartamu itu, sehingga ayahmu - secara tidak langsung-lebih berhak atas hartamu dibanding dirimu sendiri. Maka, jangan pelit kepada keduanya, karena balasan bagi keduanya adalah menafkahi dan memberikan kewenangan selama harta tersebut

34 Agus M. Najib and Fatma Amilia, "Keluarga Maslahah," in Membangun Keluarga Sakinah Dan Maslahah, by Waryono A. Ghafur and Moh Isnanto (Yogyakarta: PSW UIN SUKA, 2006), 128. 
dimanfaatkan dalam jalan yang halal, yang tidak menyimpang dari syari'at agama.

\section{Ayah Pintu Surga}

Salah satu penyebab seseorang dapat masuk surga adalah ketaatan kepada sang ayah. Hal ini dapat dipahami dari hadis Rasulullah saw. yang berbunyi:

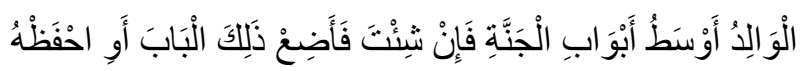

"Ayah itu adalah sebaik-baik pintu surga, seandainya kamu mau, siasiakanlah pintu itu, dan jika engkau mau, jagalah ia”

Dengan metode takhrïj bi al-lafzh $h^{35}$, penulis menemukan informasi bahwa hadis ini ditakhrij oleh Turmuż $\bar{i}^{36}$ sebanyak satu jalur, Ibn Mājah ${ }^{37}$ sebanyak 2 jalur, dan Ahmad ibn Hanbal ${ }^{38}$ sebanyak satu jalur.

Adapun yang penulis teliti dalam kesempatan ini adalah periwayatan melalui jalur Turmuzi dengan teks lengkap hadis sebagai berikut:

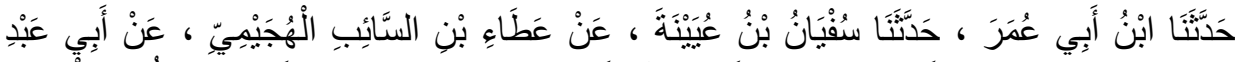

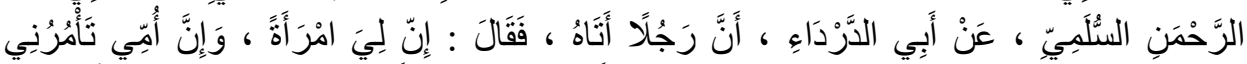

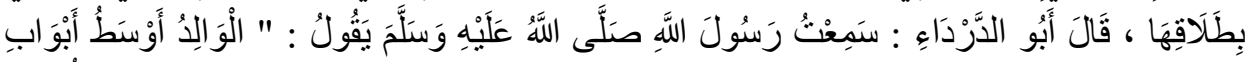

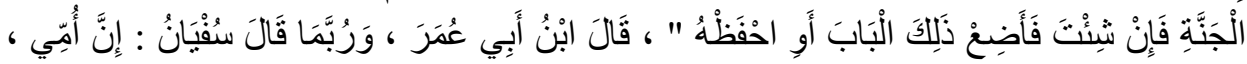

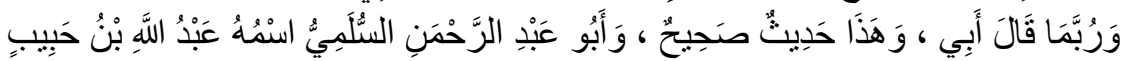

Setelah diteliti secara cermat terhadap para perawi hadis ini, yakni Ibn Abī 'Umar ${ }^{39}$, Sufyān ibn 'Uyaynah ${ }^{40}$, 'Ațā' ibn al-Sā'ib al-Hujaymī" ${ }^{-11}$, Abū 'Abd al-Rahmān al-Sulamī ${ }^{42}$, dan Abū al-Dardā' ${ }^{\prime 3}$ ditemukan bahwa

${ }^{35}$ Weinsink and Mansink, Al-Mu'jām Al-Mufahrasy, 7, 207.

${ }^{36}$ Turmudzi, Sunan At-Turmudzi. Kitab al-Birr wa al-Ṣilah, bāb Mā Jā’a min alFaḍli fĩ Riḍa al-Wālidain, hadis nomor 1818.

${ }^{37}$ Ibnu Majah, Sunan Ibnu Majah (Beirut: Dar al-Kutub al-Ilmiyah, 2012). kitāb alțalāq, bāb al-rajul ya'muruhu abūhu bițalāq imra'atahu, hadis nomor 2080 dan 3661

${ }^{38}$ Ahmad ibn Hanbal, Musnad Ahmad Ibn Hanbal. hadis nomor 26860

${ }^{39}$ al-'Asqalani, Tahzib Al-Tahzib, 5, 331-32.

${ }^{40}$ Ibid., 2, 357-60.

${ }^{41}$ Ibid., 4, 130-33.

42 Ibid., 3, 121-22.

${ }^{43}$ Ibid., 4, 428-29. 
hadis ini berkualitas shahih. Hal dikarenakan para perawinya dinilai oleh para ulama kritikus hadis sebagai periwayat yang 'adil lagi dhabith, serta tidak terdapat kecacatan dan kejanggalan dalam teks hadis ini.

Taat kepada kedua orang tua merupakan kewajiban yang harus dijunjung tinggi dan harus menjadi perhatian besar bagi seorang anak. Kewajiban ini tidak hanya kepada ibu, tetapi dalam beberapa kesempatan Rasulullah juga menekankan ketaatan kepada ayah.

Hadis ini dikuatkan oleh hadis yang bersumber dari Ibnu Umar ra. yang diriwayatkan Imam Tirmidzi dan Abu Dawud. Dari sahabat Abdullah bin Umar dia berkata:

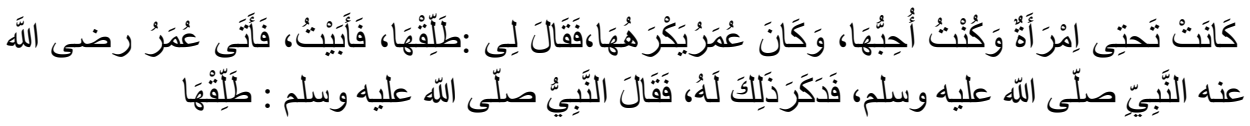

"Aku mempunyai seorang istri serta mencintainya dan Umar tidak suka kepada istriku. Kata Umar kepadaku, 'Ceraikanlah istrimu', lalu aku tidak mau, maka Umar datang kepada Nabi Shallallahu 'alaihi wa sallam dan menceritakannya, kemudian Nabi Shallallahu 'alaihi wa sallam berkata kepadaku, 'Ceraikan istrimu"' (Hr. Abu Dawud: 5138; Ibnu Majah 2088; Tirmidzi 1189.

Seorang ayah adalah sebaik-baik pintu surga. Artinya ketaatan kepadanya dan tidak menyakitinya dapat mengantarkan seseorang masuk surga melalui pintu yang paling tengah. Hal ini ditegaskan oleh AlBaidhawi, seperti dikutip Al-Munawi bahwasanya pintu itu termasuk pintu terbaik dan paling tinggi. Perbuatan paling baik yang dapat mengantarkan seseorang masuk surga adalah melalui ketaatan dan memelihara orang tua dengan baik.

Paling baik atau ausath yaitu berada di tengah-tengah di antara kedua hal. Pertama, pintu sebelah kanan diperuntukkan bagi mereka yang terbebas dari perhitungan (hisab). Lalu tiga pintu; pintu shalat, pintu puasa, dan pintu jihad. Sementara maksud dari pintu tengah adalah ketaatan kepada orang tua, dan ini menjadi pekerjaan yang tengah-tengah yang dapat mengantarkan seseorang masuk surga. Karena dari sebagian perbuatan yang paling utama dan tak pernah tertinggal adalah perbuatan 
baik. Ia hadir dalam setiap perbuatan. Maka dari itu, dalam riwayat Tirmidzi dikatakan, jika engkau mau sia-siakan saja, dan jika engkau mau jagalah. ${ }^{44}$

Meskipun ibu memiliki keutamaan, tetapi ayah juga mendapatkan porsi yang seimbang dalam haknya untuk dipatuhi. Menaati ayah serta tidak mendurhakainya adalah sebagian perbuatan yang harus dilaksanakan yang dapat mengantarkan seseorang masuk ke dalam surga, karena menaati perintah ayah adalah pintu surga yang paling baik dan paling tinggi (mulia). Maka di antara amal terbaik untuk membawa seseorang masuk ke dalam surga adalah dengan cara menaati dan menghormati ayah.

Ibnu al-Qayyim menyatakan dengan mengutip pendapat Imam Ahmad bin Hambal bahwa seorang ibu memiliki tiga hak kebaikan. Namun dalam kesempatan lain ia juga mengatakan bahwa seorang ayah memiliki hak untuk ditaati, sementara perbuatan baik seorang anak menjadi hak bagi ibu. Hal ini didasarkan pada hadis Ibnu Umar di atas. Sejalan dengan itu semua disebutkan pula dalam hadis yang bersumber dari Abu Umamah, suatu ketika seorang laki-laki mendatangi Rasulullah seraya berkata: "Wahai Rasulullah, apakah hak orang tua atas anaknya." Kemudian beliau menjawab, "Keduanya adalah surgamu sekaligus nerakamu." Karena itulah, pada akhir hadis Abu Darda diperintahkan, jika engkau mau sia-siakanlah pintu itu, atau menjaganya. Karena pintu tersebut bisa menjadi surga bagi seorang anak yang mau menaati dan menjaga orang tuanya, sekaligus bisa menjadi pintu neraka baginya tatkala ia tidak mau memalihara dengan menaati ayahnya, dan berlaku kasar kepada keduanya. ${ }^{45}$

Dalam sebuah tatanan keluarga, seorang ayah memiliki peranan yang sangat penting yang juga wajib ditaati. Keringat seorang ayah dalam mencari nafkah untuk keluarga tidak bisa disampingkan. Bisa jadi tetesan

\footnotetext{
${ }^{44}$ Abdur Rauf al-Munawi, Faidh Al-Qadir (CD Maktabah Syamilah, versi 02.11, n.d.), 6, 481 .

${ }^{45}$ Abadi, 'Aun Al-Ma'Bud, 11, 180.
} 
keringat ayah bisa disamakan dengan pahala seorang ibu yang menyusui anaknya. Karena ayah memegang peranan utama dalam keluarga, maka ia pun sosok yang pertama kali harus mempertanggungjawabkan keutuhan dan amanat anak-anaknya. Ayah menjadi pemimpin dalam sebuah keluarga, dan kepadanya pula pertanyaan perihal tanggung jawab tersebut, seperti dalam sebuah Nabi:

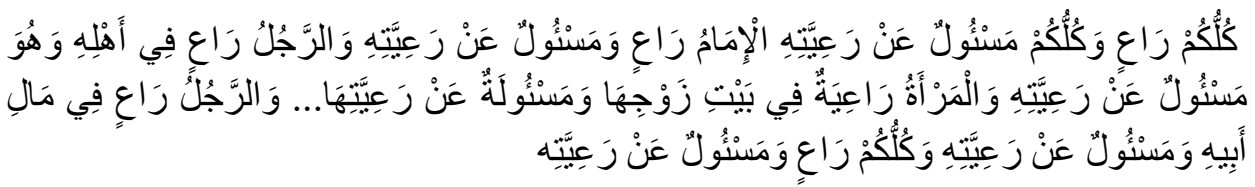

"Tiap kalian adalah pemimpin dan akan mempertanggungjawabkan kepemimpinannya. Imam itu pemimpin, akan dimintai pertanggungjawaban atas kepemimpinannya. Suami itu pemimpin keluarga, akan dimintai pertanggungjawaban atas kepemimpinannya. Istri itu pemimpin di rumah suaminya, akan dimintai pertanggungjawaban kepemimpinannya... Anak laki-laki penjaga harta ayahnya, dan akan dimintai pertanggungjawaban atas kepemimpinannya."

Hadis ini tidak sebatas menjelaskan posisi suami sebagai pemimpin dalam keluarga, tetapi ia adalah sosok yang pertama kali akan dimintai pertanggungjawaban atas kepemimpinannya. Termasuk dalam usaha menyelamatkan diri dan keluarga dari api neraka, seperti dalam firmanNya dalam surat at-Tahrim [66]: ayat 6,

Hai orang-orang yang beriman, peliharalah dirimu dan keluargamu dari api neraka yang bahan bakarnya adalah manusia dan batu; penjaganya malaikat-malaikat yang kasar, keras, dan tidak mendurhakai Allah terhadap apa yang diperintahkan-Nya kepada mereka dan selalu mengerjakan apa yang diperintahkan. (QS. At-Tahrim [66]:6)

Jika ditelaah lebih jauh, siapakah yang pertama kali bertanggungjawab atas keluarganya? Tentu berdasarkan hadis tentang kepemimpinan akan menunjuk kepada seorang ayah. Maka ayat tersebut pasti ditujukan kepada ayah yang harus menjadi garda depan dalam membentengi diri dan keluarganya dari api neraka. Ia adalah sosok yang harus memberikan pendidikan kepada keluarganya untuk takut kepada 
Allah dan menjauhi larangan-larangan-Nya. memberikan nasihat dan membekalinya dengan akhlak dan adab-adab untuk menjalani kehidupan, sehingga menjadi keluarga yang mampu menangkap rahmat dan pencerahan untuk menjauhi neraka yang bahan bakarnya dari manusia dan batu. ${ }^{46}$

Di samping itu, seorang ayah adalah pendidik yang selalu dijadikan teladan bagi anak-anaknya. Seperti disinggung oleh Nabi dalam sebuah hadis yang ditujukan kepada para ayah, meskipun ini juga meliputi ibu. Rasulullah saw. bersabda, "Berbuat baiklah kepada ibu bapakmu, niscaya anak-anakmu akan berbuat baik kepadamu. Dan jagalah kehormatan dirimu, maka istri-istrimu akan mejaga kehormatan dirinya." (Hr. ath-Thabrani)

Ungkapan Nabi di atas memberikan isyarat kepada seorang ayah untuk senantiasa berbuat baik kepada ayah dan ibunya. Karena dari teladan konkret tersebut anak-anak mereka pun akan mengikuti untuk taat kepadanya. Perbuatan baik atau dalam bahasa Arab disebut sebagai albirru berarti seluruh kesatuan perbuatan baik, termasuk perbuatan ihsan, berkata benar, taat dan patuh, juga menyambung silaturahmi dan berbuat baik dalam pergaulan. ${ }^{47}$

Demikianlah, peran ayah sangat berpengaruh dalam keluarga dan pembetukan karakter anak, seperti dapat disaksikan dalam berbagai kisah dalam Al-Quran mengenai peran ayah bagi anak-anaknya. Misalnya dalam kisah Ibrahim dan Ismail yang terekam dalam surat as-Shaffat ayat 100 dan seterusnya. Juga dalam pendidikan ketauhidan dan akhlak yang diajarkan oleh Luqman al-Hakim kepada anaknya. Seorang ayah adalah penggembala di dalam keluarganya, dan ia bertanggung jawab terhadap gembalaannya itu. Dan seorang wanita adalah penggembala di dalam rumah suaminya dan ia bertanggung jawab terhadap gembalaannya itu. Istri menjadi manajer pengelola rumah tangga, termasuk pelaksana dalam pendidikan anak. Karena itulah, Allah menganugerahkan kepada

\footnotetext{
${ }^{46}$ Al-Baidhawi, Anwar At-Tanzil (Beirut: Dar al-Fikr, n.d.), 5, 357.

${ }^{47}$ Ath-Thabrani, Al-Mu'jam Al-Ausath, 3, 13.
} 
perempuan perasaan yang halus, ketabahan, dan pendekatan yang lebih bersifat emosionil. Sementara suami atau laki-laki diberikan kekuatan raga, pikir, dan zikir agar mampu menjadi pembela, pendidik, sekaligus pembawa obor keimanan menuju keluarga yang damai, aman, kasih sayang, dan penjemput rahmat Allah melalui zikir dan doanya.

\section{PENUTUP}

Secara kualitas, ketiga hadis yang diteliti berada pada posisi maqbūl, yakni dapat diterima sebagai hujjah. Sehingga, tidak ada keraguan bahwa ia benar-benar berasal dari Rasulullah saw.

Makna yang terkandung dalam ketiga hadis yang diteliti ini secara umum menekankan betapa pentingnya peran seorang ayah dalam kehidupan seorang anak. Membenci ayah akibatnya adalah membuat seorang anak jatuh dalam kekufuran. Seburuk apapun kondisi seorang ayah, anak tidak boleh membencinya apalagi tidak mengakuinya. Ancaman dosa besar diberikan oleh Nabi terhadap orang yang melakukan perbuatan tersebut. Kebaikan seorang anak terhadap ayahnya, pun harus diwujudkan dalam bentuk santunan berupa harta kepada beliau. Tidak salah bila seorang ayah mengambil harta anaknya, meski sang anak sudah berumah tangga. Asal, yang diambil dalam porsi normal untuk kebutuhan hidup sang ayah, bukan untuk menghambur-hamburkannya yang akan menyengsarakan sang anak.

Pengabdian anak kepada ayahnya juga dapat berdampak pada keridhaan Allah swt. yang akan menjadi penyebab sang anak masuk ke surga-Nya. Menyia-nyiakan ayah, akan dapat menghambat seseorang merasakan nikmatnya surga Allah, karena ayah adalah sebaik-baiknya pintu surga. Bagaimana bisa seseorang masuk surga bila sang pintu tidak mau terbuka. Menghormati ayah dan berbuat baik kepadanya, akan membuat pintu itu terbuka.

Kebaikan yang diperbuat oleh seorang anak, tentu tidak terlepas dari proses pendidikan yang diberikan sang ayah kepadanya. Bila sang ayah tidak mendidik anaknya dengan baik dan tidak memberi tauladan yang 
semestinya, tentu sulit diharapkan sang anak akan memberikan baktinya dengan maksimal. Oleh karena itu, hubungan ini bentuknya adalah timbal balik. Untuk bisa memiliki anak yang berbakti, sang ayah harus mendidiknya dengan sebaik-baiknya dan memberi contoh terbaik untuknya.

\section{DAFTAR PUSTAKA}

Abadi, Abu ath-Thayyib Muhammad Syams al-'Azhim. 'Aun Al-Ma'Bud.

CD Maktabah Syamilah, versi 02.11, n.d.

Abu Dawud, Imam. Sunan Abu Dawud. Beirut: Maktab ad-Dirasat wa alBuhuts fi Dar al-Fikr, n.d.

Abu Syuhbah, Muhammad. Fi Rihab Al-Sunnah Al-Kitab Al-Shihah AlSittah. Kairo: Majma' al-Mabhuts al-Islamiyyah, n.d.

Ahmad ibn Hanbal. Musnad Ahmad Ibn Hanbal. Beirut: Dar Ihya' alTurats al-'Araba, 1993.

Al-Baidhawi. Anwar At-Tanzil. Beirut: Dar al-Fikr, n.d.

Al-Bukhari, Muhammad Isma'il. Shahih Al-Bukhari. n.p: Dar Ibn Katsir, 1993.

Al-Naisabury, Muslim ibn Hujjaj Al-Qusyri. Shahih Muslim. Beirut: Dar Ihya' al-Kutub al-'Arabiyah, n.d.

'Asqalani, Syihab al-Din Abu al-Fadhl Ahmad ibn Hajar al-. Fath AlBari. Beirut: Dar al-Fikr, 1996.

- Tahzib Al-Tahzib. Beirut: al-Turas al-`Arabi, 1993.

Ath-Thabrani, Al-Imam. Al-Mu'jam Al-Ausath. Beirut: Dar al-Kutub alIlmiyah, 2012.

Dagun, Save M. Psikologi Keluarga: Peran Ayah Dalam Keluarga. Jakarta: PT. Rineka Cipta, 2013.

Gadamer, Hans-Georg. Truth and Method. Translated by Ahmad Sahidah. Yogyakarta: Pustaka Pelajar, 2004.

Ghazali, Muhammad al-. Sunah Nabi Menurut Ahli Fiqh Dan Ahli Hadis. Translated by Halid. Jakarta: Lentera, 2004. 
Hanafi, Hassan. Islamologi 3: Dari Teosentrisme Ke Antroposentrisme. Translated by Miftah Faqih and Fuad Mustafid. Yogyakarta: LKis, 2011.

Ibn Jarir Al-Tabari, Abu Ja'far Muhammad. Jami' Al-Bayan: 'an Ta'wil Ay Al-Qur'an. Beirut: Dar al-Kutub al-Ilmiyah, 2009.

Ibnu Batthal, Abu al-Hasan 'Ali ibn Khalaf ibn 'Abd al-Malik. Syarah Shahih Al Bukhari Li Ibni Batthal. n.p: Maktabah al-Rusyd, 2008.

M. Najib, Agus, and Fatma Amilia. "Keluarga Maslahah.” In Membangun Keluarga Sakinah Dan Maslahah, by Waryono A. Ghafur and Moh Isnanto. Yogyakarta: PSW UIN SUKA, 2006.

Majah, Ibnu. Sunan Ibnu Majah. Beirut: Dar al-Kutub al-Ilmiyah, 2012.

Mantzavinos, C. "Hermeneutics." In The Stanford Encyclopedia of Philosophy, edited by Edward N. Zalta, Winter 2016. Metaphysics Research Lab, Stanford University, 2016. https://plato.stanford.edu/archives/win2016/entries/hermeneutics/.

Mudji Raharjo, and Zainal Habib. Hermeneutika Gadamerian; Kuasa Bahasa Dalam Wacana Politik Gus Dur. Malang: UIN Malang Press, 2007.

Munawi, Abdur Rauf al-. Faidh Al-Qadir. CD Maktabah Syamilah, versi 02.11, n.d.

Najwah, Nurun. "Tawaran Metode Dalam Living Hadis." In Metodologi Penelitian Living Qur'an Dan Hadis, by Muhammad Mansyur. Yogyakarta: Teras, 2007.

Slameto, Slameto. "Peranan Ayah Dalam Pendidikan Anak Dan Hubungannya Dengan Prestasi Belajarnya." Jurnal Satya Widya 15, no. 1 (2002).

Suryadi. "Metode Pemahaman Hadis Nabi (Telaah Atas Pemikiran Muhammad Al-Ghazali Dan Yusuf Al-Qardhawi)." Program Pascasarjana UIN Sunan Kalijaga, 2004.

Turmudzi, Imam. Sunan At-Turmudzi. Beirut: Dar al-Fikr, 1994.

Weinsink, A. J., and W.Y. Mansink. Al-Mu'jam Al-Mufahrasy Li Alfazh Al-Hadits Al-Nabawi. Leiden: Brill, 1965. 